\title{
TRANSFORMATION OF TOURIST LANDSCAPES IN MOUNTAIN AREAS: CASE STUDIES FROM SLOVAKIA
}

\author{
Branislav Chrenka*, Vladimír Ira \\ Institute of Geography, Slovak Academy of Sciences, Štefánikova 49, 81473 Bratislava, Slovak Republic
}

\begin{abstract}
After two decades of deregulated free market economy the post-socialist rural mountain areas are being unprecedently commodified. Landscapes of tourist consumption with specific behaviour patterns are produced and reproduced. The paper explores how landscapes are transformed due to massive investments into tourist infrastructure with questionable impacts on quality of life and environmental sustainability. Power relations and related production of space are analysed in three case studies in the selected mountain areas in Slovakia. First, the Oščadnica case study reflects on rural landscape rapidly transformed by massive ski resort development and deforestation. Second, the Tále golf course development case study describes commodification and gentrification processes in Central Slovakia. Third, the High Tatras case study explores how power structures push on the transformation of the oldest and most visited National Park in Slovakia.
\end{abstract}

Key words: Tourist landscape, Transformation, Power structures, Quality of life, Impact of tourism, Slovakia.

\section{Introduction}

This paper deals with subjectively selected, smallscale landscapes that represent only a little share from the surface in the mountain areas in Slovakia. Most of the mountain areas remain relatively untouched by tourism infrastructure development, or face different consequences of human interference. Massive deforestation is the most striking and the most visible one, reasoned as a response to „barkbeetle" calamity by forest managers. In certain areas, this phenomenon coexists with or even influences the phenomenon of tourism infrastructure development. All in all, in this paper we do not aim to provide an analysis of the case studies that would represent a typical mountain area in Slovakia (if there is one). Alternatively, our focus is on few selected landscapes that have been recently (and are still being) transformed by massive tourism infrastructure development. Visiting these mountain landscapes may be fun for some, but disappointment for the others. Billboards, teasing slogans, hotels, cable-cars, and parking lots infiltrate into villages, valleys, meadows, forests, rocks, mountain lakes, creating playgrounds that serve predominantly urban population or rather part of the urban population. Let

${ }^{*}$ Corresponding author:

Email: branislav.chrenka@savba.sk us not beat about the bush. It is difficult to avoid some personal sentiment when the meadows where one used to play as a child are now occupied (privatized) by golf resort and his right to access the area is denied. Or when a situation in the High Tatras where the 2004 windstorm devastated 12,600 ha of the coniferous forests is being partly (mis)used for the plans and wishes of tourism developers.

The paper aims to provide a theoretically based case studies analysis of the processes related to a socio-spatial transformation of mountain landscapes by tourism infrastructure development. The theoretical part consists of three themes framing the issue. The first is theorizing landscape from the point of its dichotomic character (subject vs. object) and changing human behaviour patterns related to the landscape. This provides a departure point for the central theoretical theme, conceptualization and (trans)formation of tourist landscapes with related socio-spatial processes. The last theoretical theme follows - how these tourist landscapes are being (re)produced and represented by the media and promotion? The empirical part deals with three case studies reflecting the foregoing theory. First, the Oščadnica case study reflects on rural landscape rapidly transformed by massive ski resort development and deforestation. Second, the Tále golf course development case study describes commodification and gentrification processes in 
Central Slovakia. Third, the High Tatras case study explores how power structures push on the transformation of the oldest and most visited National Park in Slovakia.

\section{Landscape and tourism in the era of transformation}

\section{Theorizing landscape}

Do landscapes exist for their own sake or for human use? The subject-object dichotomy debate has been a topic between so-called biocentrists and anthropocentrists over centuries. The European Landscape Convention defines the landscape as an area „as perceived by people, whose character is the result of the action and interaction of natural and/or human factors" (Council of Europe, 2000). Human perception is essential here, what detaches the landscape from its substantive character. Mentioning "result" also puts the landscape into position of a passive player in production of space. Are we in this relationship between human and landscape still capable to recognize its inherent quality? Or do we consider landscape to be just a resource, just like its parts - trees, minerals or water? Despite the utility of landscape scenery has a long tradition in European perception; only after the WWII it has been labelled a resource. The process of human detachment from the land and „aesthecisation“ of nature relates to subsequent quest for preservation of outstanding physical landscapes (Evernden 1981). It is irony that the same „aesthecisation“ of mountain landscapes that caused foundation of protected natural areas brought along unprecedented pressure in form of massive tourism infrastructure development. Exploitation of landscapes in post-modern era continues in a new form.

Visual aspect of the landscape was intensely questioned by some critical geographers whose aim was to focus on power relations forming landscapes, including the themes of morality, justice and law (Mels and Setten 2007). „Powerscape“, the concept introduced by Olwig (2005), stands for substantive nature of landscape and raises questions „what we use landscapes for, under which circumstances, in what ways and for whom". Another approach of questioning „intellectual and emotional tyranny of visual landscapes" is by means of introducing personal attachment forming the inner landscapes that bring us back to all our senses (Bunkše 2007). The essential condition of understanding landscape here is "to be there" and bodily interact with it (walk it, see it, hear it, touch it, smell it). However, Benediktsson (2007) observes where this "scenophobic" approach of critical geographers led to in practice. According to him, scholars stuck in intellectual debates about the "substance“ of landscape and detached from its visual quality loose their voice in questioning massive investment projects transforming (devastating) natural landscapes. Benediktsson (2007) points out how a single photography (visual embodied practice) moved public perception of the Iceland landscape quality in hydroelectric plant project. Visual quality of the landscape can be assessed by either normative, behavioural or preferably by combined approach, as Otahel (2003) describes it.

Possible framework for understanding changing human behaviour patterns related to landscape is provided by Antrop (2005), further developed by Novák (2007). According to the authors, three historical periods can be recognized: „traditional landscapes" with diverse functions of land use structures, "landscapes of the revolutions age“ with predominantly productive functions (agriculture and industry) and „post-modern new landscapes“ with ecological and recreational functions. „Traditional landscapes" are the most difficult to sustain in postmodern era, but conceptualized as a "heritage" they are also heavily subsidized in the European Union. The concept of heritage is effectively used to make traditional European landscape "sustainable“ (Chrenka 2010). The impact of tourism on contemporary landscape change is reflected also in Vos and Klijn's (200o) recognition of the trends of the transformation in European landscapes. Specific tourist and recreational forms of land are the main driving forces alongside urban sprawl, intensification of agricultural production in densely inhabited areas, and extensification of land use in less favoured areas.

\section{(Trans)forming tourism landscapes}

„Capitalism inherits a geographical structure... but as ever it transforms what it inherits."

Smith 2008:190

„Space, place and landscape - including landscapes of leisure and tourism - are not fixed but are in a constant state of transition as a result of continuous, dialectical struggles of power and resistance among and between the diversity of landscape providers, users and mediators."

Aitchinson 1999:29

Landscape transformation related to tourism development needs to be put into context of social, economic, cultural and political processes that create a comprehensive framework for critical analysis. The „critical turn" in tourism studies has been introduced mainly by Britton's (1991) notions of the capitalist nature of tourism activities and putting tourism into context of territorial competition and restructuring. Britton considers tourism to be „one of the most 
important elements in the shaping of popular consciousness of places and in determining the creation of social images of those places“. He also emphasizes the position of tourism in current concerns of critical geographers, such as the transformation of rural economics, political struggles over the spatial division of space and the creation of new „postmodern“ and vernacular landscapes. However, cultural aspects of tourism were studied even before Britton's influential paper (MacCannell 1976, Culler 1981, Urry 1990a). As MacCannell puts it, „tourist experiences need to be regulated and made predictable before they can be profitable“. The same applies for tourist landscapes - their regulation is a precondition of commodification. According to Terkenli (2002), tourism as one of the dominant systems of consumption creates landscapes where cultures of production and consumption predominate in ways both actual and symbolic. Terkenli's „new cultural economy of space“ describes the process of tourist landscape transformation in four types: „enworldment“ as production of seductive landscapes serving mass tourism; „unworldment“ as a phase of unregulated functions, placelessness, inauthenticity and loss of identity; „deworldment“ as creation of commercialized, „disneyfied“, surreal places; and „transworldment" as dissolution of cultural boundaries characteristic of the post-modern age and creation of „semiotic“ landscapes. At the end the main landscape characteristics is neither nature nor identity, but a product.

Critical turn meant taking social and cultural aspects of tourism seriously. According to Minca (2007), ambivalent landscape characteristics (landscape-as-essence and landscape as a way of seeing) in tourism can not be avoided, but only endlessly socially performed. The tourist "performance“ is a metaphor used to describe how tourist space is reproduced, challenged, transformed and bypassed (Edensor 2001). However, focusing on performative aspects came in for criticism in the view of neglecting political and economic aspects related to power struggle over the tourist space (Bianchi 2009). Klein (2001:124) criticizes postmodern leftists of failing to challenge restructuring of class power: „we were too busy analyzing the pictures on the wall to notice that the wall itself had been sold“. Land privatization for tourist production and consumption together with the related control of space is conceptualized by Marxist geographers as „production of nature“ (Smith 2008). Smith envisages human society as placing itself at the centre of nature what creates the quest of capital to control nature. In commodified tourist landscapes, their „naturalness“ is emphasized by tourist industry to create consumption. Other ways of seduction (e.g. nationalism as a mode of belonging) are in play as well.

Church and Ravenscroft (2007) point out that one of the main features of capital - its mobile, fluid character - is not completely relevant in tourism industries, as the physical sights and tourist resorts are spatially fixed. Therefore, different power resources - property and the law - must be taken into consideration. Process of „creative destruction“ in spatially fixed (built) environment as described by Harvey (2006) is well observable in transforming post-socialist economies.

As any productive sector, tourism brings negative impacts and positive effects for tourism landscapes at local, national and global levels. Tourism's relationship with the environment is complex. On the one hand, tourism has the potential to create beneficial effects on the environment by contributing to environmental protection and conservation, on the other hand, it involves many activities that can have adverse environmental effects. The socio-cultural impacts of tourism are the effects on host communities of direct and indirect relations with tourists, and of interaction with the tourism industry. The tourism impacts can cause changes in value systems and behaviour and thereby threatens indigenous identity. Changes often occur in community structure, family relationships, collective traditional life styles, ceremonies and morality. But tourism can generate positive impacts (e.g. fostering pride in cultural traditions, avoiding emigration/relocation by creating local jobs). Sociocultural impacts are often ambiguous. The tourism industry can generate substantial economic benefits to both host regions (landscapes) and tourists' home countries. As with other impacts, this massive economic development brings along both positive and negative consequences (UNEP 2003, Ira 2005). In the tourist landscapes the search for sustainable balance between sometimes conflicting goals of conserving biodiversity, promoting economic development and maintaining associated cultural values should be handled as a platform for democratic discussion in which all relevant stakeholders are involved (Kušová et al. 2008).

However, in transforming tourist landscapes, neither their physical nor symbolic (identity) aspects are a result of solely democratic discussion. According to Saarinen (2004), the identity of tourist destination is constructed by two discourses. The discourse of region (place) is related to our knowledge and meaning of the destination. It is created by travel literature, guide books, advertisement and the like. The discourse of development (action) relates to the institutional practises and policy creating destinations. It is formed by planning organizations, consumption, 
infrastructure and the like. Discourses of tourist destinations and their landscapes are (re)produced by their representation in media and promotion. Therefore, the following part describes several ways how to conceptualize this issue.

\section{Reproduction and representation of tourist landscapes}

Although tourism has sometimes been regarded as an academic backwater by geographers, its role in shaping contemporary landscape is significant. „Tourists tour, consume, and represent landscapes, places and cultures that have been produced, presented and represented by tourism marketing“ (Morgan 2004:173). Place promotion became an influential tool in shaping mental image of tourist destinations and their landscapes that affects tourists' spatial behaviour, preferring certain landscapes to others. Following Ward (1998) and Morgan (2004), we can divide „behavioural“ and „critical“ approach in analysis of tourist promotion. Behavioural approach based on psychological premises of behavioural geography is concerned with marketing (e.g. destination branding) and public policy issues. The central concept is the place image and identity formation. How landscapes are represented, modified and (mis)used in place promotion to create demand? Content (quantitative - frequency of words etc.) and semiotic (signs and their meanings) analysis is used for the enquiry. Critical approach stems from the „cultural turn“ in social sciences and is based on critical theory. Landscapes are not seen as politically neutral, fixed and objective, but as symbolic, mutable, subjective and culturally constructed mixtures of representation and physical form. Power is the central concept here. They represent, reinforce and naturalize sociocultural power relations (Morgan 2004). According to Massey (1993), representations are always political as they reinforce and legitimize certain conceptualizations of places (landscapes) of those who influence the media. Power struggle between various interest groups is described by discourse analysis.

Much of the previous research on tourism has concentrated on the sense of sight (e.g. Urry 199ob). While general studies of landscape perceptions and scenic beauty represent some well-established traditions, only very few studies of tourists' perceptions and preferences for various types of landscapes have been conducted. Little is known about how "ordinary" people perceive the landscapes they experience during their holidays. In addition, landscape-related decision-makers have a relatively unclear idea of various recreationists' landscape preferences (Fyhria et al. 2009).

It is widely acknowledged in the study of the people - tourist landscape interaction that the acquisition of environmental information, and the use of that information in some form of decisionmaking process, serves as a prelude to overt or "ate out" behaviour (Walmsley et al. 1993: 95). Environmental (landscape) images or images of place can be thought as learned and stable mental conceptions that summarize individual's knowledge, evaluation and preferences (Pocock and Hudson 1978). Human behaviour is mostly dependent upon an image built up of information derived from the social and physical milieu (Powell 1978). In this sense image can be thought as a part of the (socio-political) culture in which develops.

\section{Three case studies from mountainous tourist landscapes in Slovakia}

\section{Vel'ká Rača ski resort}

Vel'ká Rača ski resort is located in the commune Oščadnica in Kysuce region (Northern Slovakia) bordering Poland and Czech Republic (figure 1). The formerly poor peripheral region with a high rate of unemployment, unfavourable climate conditions for intense agriculture and lack of industries is today becoming an international transport corridor in north-south direction. Predominantly forested landscape does not provide abundance of exceptional natural attractiveness. The region keeps rural atmosphere in remote areas, whereas central areas are relatively densely inhabited. Oščadnica is one of the most populous and spacious rural communes in Slovakia.

The first ski lifts below the peak of Vel'ká Rača $(1236 \mathrm{~m})$ were built in 1972. Intense development of the resort and rapid growth in annual visit rate took place from 1999 until 2006. The mayor of Oščadnica together with several private investors stood behind its rapid development. Whereas in 1990's there were about 40 thousands of visitors per year, until 2006 the number grew tenfold. Unemployment rate dropped from 27 to 7 percent, people were motivated to set up a business and Oščadnica became a synonym to successful village in the field of tourism (Blažej 2006).

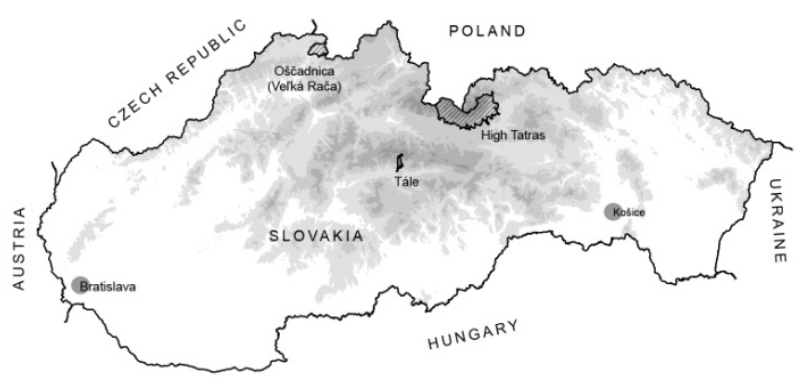

Figure 1. Locations of three case studies in Slovakia 
However, an exceeding carrying capacity was apparent in symptomatic problems such as congestions at insufficient road infrastructure, lack of bread in the stores and growing land prices. The local territorial plan allowed land privatization (photo 2) and construction of accommodation and related facilities in the formerly regulated zones. Traditional dispersed settlements (some of them in immediate proximity to cable cars) with ageing population were turned into tourist facilities.

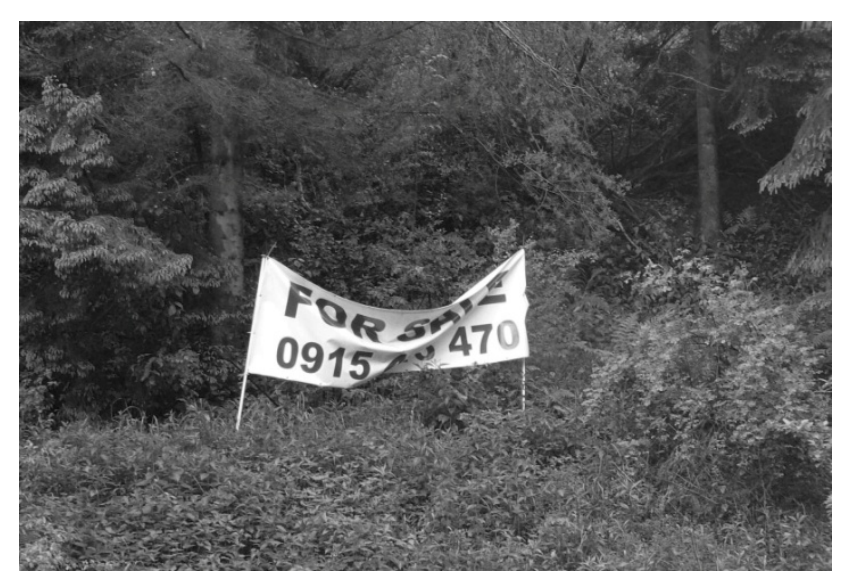

Photo 2. Vel'ká Rača - ski resort and landscape privatization

The following plan was to expand transport capacity of ski infrastructure from 9,700 persons/hour to 33,400 and Vel'ká Rača would become the largest ski resort in Slovakia, inviting 15,000 visitors a day during winter season. The massive development project also found strong support in the local territorial plan. A significant part of rural landscape (area of 1,050 ha) was designated for the ski resort development itself not including other areas with supporting facilities development. However, none of the plans materialized. Why? Despite the economic nature of tourism investments, the answer is mainly political. The project was blocked with a change of the government in 2006 when the mayor claiming for reimbursement of $95 \%$ expenses by EU funds lost influential contacts at the Ministry of Construction and Regional Development. The political power as a potential driving force of rural landscape change was lost. The drive was taken by natural forces and the lust for profit of other interest group. After the bark-beetle calamity burst, local forestry association with its logging plan caused massive deforestation in the landscape (Photo 3). Tourist landscape attractiveness has become threatened for the next decade or two.

Interestingly, place promotion either (mis)uses landscape portraits from the time before deforestation or avoids them completely. Tourist promotion creates an image of the resort as a playground not only for winter sport activities but

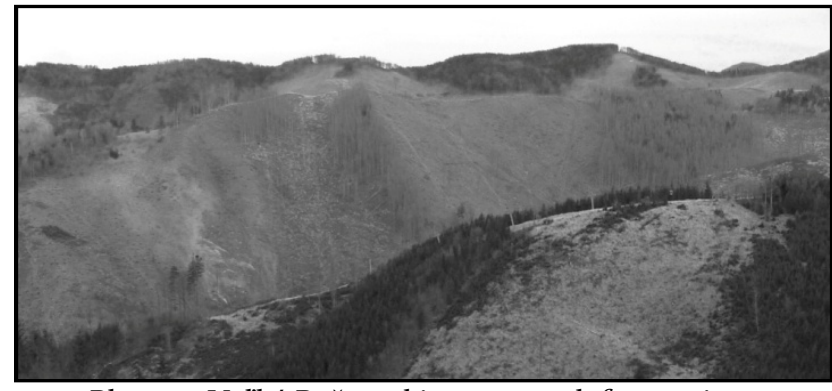

Photo 3. Vel'ká Rača - ski resort vs. deforestation

also for summer attractions (the longest bobsleigh track in Slovakia, downhill biking, rope park, trampolines, etc.) that have a potential to commodify the landscape.This image remarkably contrasts with the representation of the whole Kysuce region, which is usually depicted as ,a tranquil area of rolling hills and small farming and logging towns" (Humphreys, Nollen 200o). In economic journals (Blažej 2006), the „successful story“ of Oščadnica was strongly reproduced in the period of massive growth. The village and resort were represented as an example of business strategy for other rural localities in mountain areas. Remarkable about this place image formation was that voice was given only to investors and entrepreneurs.

\section{Tále Golf Resort}

Tále is a picturesque location in Central Slovakia at the foothills of Low Tatra mountains (figure 1). Typical feature of the landscape is a relief of coniferous forests, streams and meadows. Traditional landscape in Tále was characterized by sheep grazing and related activities. The first shift in the landscape character happened in 1960's as the first hotel was built in this area. Tále was gradually transformed into a recreational zone. Artificial lake for swimming, simple wooden huts, cafeteria and restaurant were built here. The whole zone was focused on organized recreation of trade unions and average-income families. After 1989, this type of recreation lost its function. In 1990's, simple wooden huts were kept in operation, however the needed reconstruction did not take place. Instead, in 1998, extensive development project of a golf resort was presented by the general director of the largest industrial company in the region - Podbrezová Metalworks.

Over five years, the US designers company together with the Slovak landscape architects was transforming the tourist landscape of Tále. The area has been privatized and access is strongly regulated. Photographing is prohibited, as well as access to the golf courses. „Tourist gentrification“ related to the landscape change prioritizes wealthier clientele and regulates tourist behaviour. Signs discourage from entering the courses by mentioning "guard-dogs“ 
(Photo 4). Behind a wooden fence, simple wooden huts face successive stages of decay (Photo 5). Abandoned area stands in a sharp contrast with the aesthecized golf landscape. Process of „creative destruction" (Harvey 2006) is evident in transformation of 60 ha of tourist landscape.

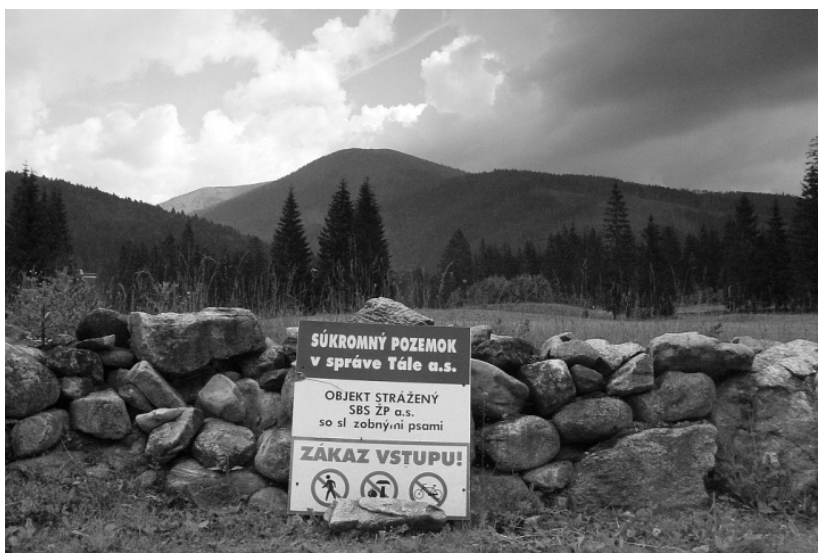

Photo 4. Tále - privatized tourist landscape

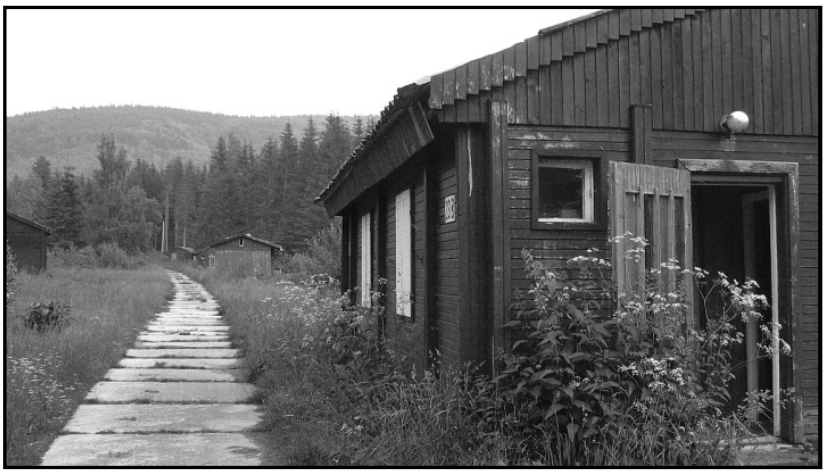

Photo 5. Tále - post-tourist landscape in decay

\section{Tatry Mountain Resorts}

The High Tatras is the highest mountain range of the whole Carpathians and the core of the oldest (1949) National Park in North Slovakia (figure 1). During 16$17^{\text {th }}$ centuries, the area was extensively deforested and turned into grazing land. Due to their attractiveness, the High Tatras became a popular tourist destination as early as at the end of the $19^{\text {th }}$ century. Tourist function was gradually replacing silvicultural and agricultural activities in the area. The romanticist quest of Hungarian nobility for aesthetic mountainous landscape led to the development of the first resorts. The first balneal facilities were built in 1839 in Starý Smokovec (Kollár et al. 1998). In Tatranská Lomnica, several luxurious hotels were built in the 1900's and the first cable cars was put into operation in 1930-1940's. Štrbské Pleso was intensively developed since the 196o's into the top ski resort, where the 1970 World Nordic Ski Championship and the 1987 Winter Universiade took place. After 1989, obsolete tourist infrastructure and lacking quality services caused decrease in numbers of visitors. The 1990's was a period of forming several strong financial groups on the basis of privatization.

In the next decade, the Tatry Mountain Resorts (TMR) company as a major investor in the field of tourism in the High Tatras region was formed. Promoted slogans „New era of Tatras“ (Photo 6) and „Tatras regeneration project“ are presented not only as a solution for the „underinvested“ region, but also as a response to the windstorm calamity that changed the aesthetics of the forested landscape in Tatras during a single night in November 2004. The devastated area of 12,600 ha became not only a subject of dispute between foresters and environmentalists, but also a symbol of the new start and an excuse for new development plans. TMR is currently investing $€ 135$ mil. into tourism development in High and Low Tatras, predominantly into construction of ski slopes and related facilities. The strategy of TMR is „continual increase in numbers of visitors in the resorts“. The priority is to increase the transport capacity of ski infrastructure and real estates projects with a „maximum respect for the environment". Patriotism and privatization with a slogan „Buy your share of Tatras" is another important aspect of encouraging people to invest in TMR (Photo 7). Anybody can join the mass tourism development and eat his/her piece of cake. Seduction by potential profit is entwined with the power of controlling space. Purely economic power is strengthened by extra-economic, which enables anyone to write the successful story of tourism development in Slovakia.

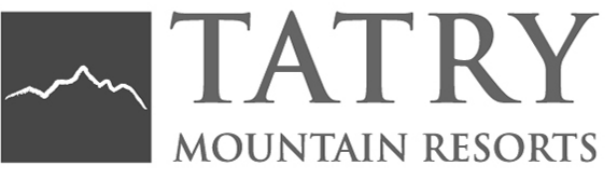

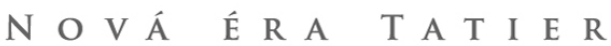

Photo 6. High Tatras - logo of the Tatry Mountain Resorts company

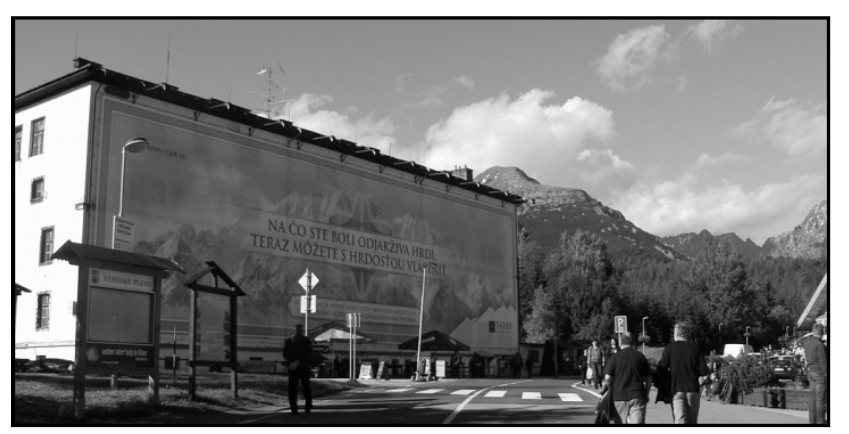

Photo 7. High Tatras - billboard capitalizing tourist landscape 
At Skalnaté Pleso, the mountain lake at 1751 metres above sea level, TMR created „Marmot landscape ecopark“. The mountain lake itself had been previously negatively affected by a cable car construction that eroded the bottom of the lake. During dry periods, the lake has no water. „Marmot landscape" is the next anthropogenic impact that needed heavy mechanisms to construct it as well as the National Park administration to approve it. Ecopark with free entrance has not been located in this altitude by chance. Families with little children as a target group are not likely to walk to 1751 metres, but to take a cable car instead. Popular daily paper Nový čas presented this project as „useful“ and as „the best place to explore wilderness“ (Nový čas, 2.7.2010). The brochure of TMR offers hiking trails that require using the cable car or the funicular train,. Soft power (marketing, promotion and seduction) is used to regulate tourist behaviour and to commodify the tourist landscape. In Smith's (2008) words, „Wilderness“, nature is paradoxically produced by a man.

\section{Conclusions}

„What have you been proud of for years, now you can proudly own“, Bohuš Hlavatý from Tatry Mountain Resorts announced (TMR 2010). Stakeholders' profit has become the driving force of tourist landscape transformations. Economic power blends together with political. To transform and to sustain the tourist landscapes, they need to be controlled. Privatization of land property in areas with high environmental protection requires approval by decision-making bodies on different levels, like a municipality, National Park administration or national ministries. Another form of merging economic and political power is identified in funding mass tourism infrastructure projects based on public-private partnership from the EU funds, like it was planned in Vel'ká Rača ski resort. However, these development projects can be halted due to political (e.g. change of the government), as well as economic (e.g. economic crisis) reasons. Transformation of tourist landscapes is not dependent only on the form and volume of capital investments, but also on local environmental context. Natural calamities (e.g. windstorm, bark beetle) as a major driving force of forested landscape change in mountain areas highly influence the potential in tourism development. On the one hand, they can restrain the aesthetics of tourist landscape, on the other, they can create new spaces and conditions for further investments. Aesthetic function of the landscape is essential for tourism performance in mountain areas.
In the Vel'ká Rača ski resort, this function was diminished by the bark beetle calamity and the subsequent massive wood exploitation by local forest managers. Tourist promotion effectively avoids the aspect of natural and cultural landscape and either focuses on representation of bodily sport activities or intentionally does not uses current images. In Tále, aesthetics of the landscape is represented by the golf resort development. Golf courses area was privatized, commodified, regulated and aesthecized, whereas the former tourist area was abandoned and its aesthetics forgotten. In the High Tatras, the forested landscape was transformed by a massive windstorm that changed its substantive aesthetic qualities. Instead of naturalness of the area, in its tourist promotion, the Tatry Mountain Resorts company as the major investor emphasizes man-made attractions and luxurious facilities that commodify the landscape.

This article was not intended to blame tourism for its impacts on landscape transformation. Undoubtedly, tourism still has a potential to create new jobs and bring economic development into mountain areas in Slovakia. The question is, what kind of tourism in these areas is needed and is it sustainable from social and environmental point of view? All the case studies presented above (not representing a „typical“ Slovak rural mountain landscape, however) share several processes stemming from the capitalist nature of tourism investments: landscape privatization, control, regulation, commodification, gentrification and reproduction by promotion. Again, this is not to say that mass tourism does not bring economic profit to local population at all, or that it is inevitably harmful for the environment. Rather, the aim was to bring more of a critical approach into tourism research (missing in the post-communist countries) and not to forget the market-oriented nature of tourism development with all the related impacts.

\section{Acknowledgements}

The authors would like to acknowledge financial support from the Science Grant Agency (VEGA) of the Ministry of Education of the Slovak Republic and the Slovak Academy of Sciences (grant 2/0191/o9).

\section{Bibliography}

Aitchison, C 1999, 'New cultural geographies: The spatiality of leisure, gender and sexuality', Leisure Studies, vol.18. nr.1, p.19-39.

Antrop, M 2005, 'Why landscapes of the past are important for the future', Landscape and Urban Planning, vol.70, p.21-34. 
Benediktsson, K 2007,: '“Scenophobia", geography and the aesthetic politics of landscape", Geografiska Annaler B, vol.89.no.3, p.203-217.

Bianchi, RV 2009, 'The 'Critical Turn' in Tourism Studies: A Radical Critique', Tourism Geographies, vol.11. no.4, p.484504 .

Blažej, J 2006, 'Vel'ká a ešte väčšia Vel'ká Rača', Trend viewed on 21.12.2006, http://relax.etrend.sk/relaxcestovanie/velka-a-este-vacsia-velka-raca.html.

Britton, S 1991, 'Tourism, capital and place: towards a critical geography of tourism', Environment and Planning D: Society and Space, no.9, p.451-478.

Bunkše, EV 2007, 'Feeling is believing, or landscape as a way of being in the world', Geografiska Annaler B, vol.89.no.3, p.219-231.

Chrenka, B 2010, 'Udržatel'nost', krajina a cestovný ruch: hladanie teoretických východísk', in P Nováček \& M Huba (eds) Udržitelný rozvoj - stav a perspektivy v roce 2010, Olomouc, Vydavatelství Univerzity Palackého, 213-222.

Church, A \& Ravenscroft, N 2007, 'Power, resource mobilisation and leisure conflict on inland rivers in England', in A Church \& T. Coles (eds) Tourism, power and Spaces, Routledge, New York.

Council of Europe, 20oo, The European Landscape Convention, Strasbourg.

Culler, J 1981, 'Semiotics of tourism', American Journal of Semiotics, no.1, p.127-140.

Edensor, $\mathrm{T}$ 2001, 'Performing tourism, staging tourism: (re)producing tourist space and practice', Tourist Studies, vol.59. no.1., 59-81.

Evernden, N 1981, 'The Ambiguous Landscape', Geographical Review, vol.72. no.2, p. 147-157.

Fyhria, A, Jacobsen, JKS \& Tømmervik, H 2009, 'Tourists' landscape perceptions and preferences in a Scandinavian coastal region', Landscape and Urban Planning, vol. 91, p. 202-211.

Harvey, D 2006, The Limits to Capital: New and Fully Updated Edition, Verso, London.

Humphreys, R \& Nollen, T 2000, The Rough Guide to Czech and Slovak Republics, Rough Guides, London.

Ira, V 2005, 'Sustainable Development, Quality of Life and Tourism', in M Hesková, E Šittler \& V Dvořák (eds) Tourism, Regional Development and Education, Reviewed Proceedings of the 1oth International Conference "Tourism, regional development and education", Katedra cestovního ruchu Tábor, Jihočeská univerzita České Budějovice, Tábor, 12-13 May 2004, p.51-56.

Klein, N 2001, No Logo, Flamingo, London.

Kollár, D, Lacika, J \& Malarz, R 1998, The Slovak-Polish Tatras, Dajama, Bratislava.

Kušová, D, Těšitel, J, Matějka, K \& Bartoš, M 2008, 'Biosphere reserves - An attempt to form sustainable landscapes - A case study of three biosphere reserves in the Czech Republic', Landscape and Urban Planning., vol. 84, no. 1, p. 38-51.
McCannell, D 1976, The Tourist: A New Theory of the Leisure Class, Schocken Books, New York.

Minca, C 2007, 'The tourist landscape paradox', Social \& Cultural Geography, vol.8. no. 3, p.433-453.

Morgan, N 2004, 'Problematizing Place Promotion', in AA Lew, CM Hall \& AM Williams (eds) A Companion to Tourism, 173-183, Blackwell, Oxford.

Novák, TJ 2007, 'Landscape changes as manifestations of changing society', in E Kallabová, B Frantál, P Klusáček (eds) Regions, Localities and Landscapes in New Europe: enhenced abstracts of Lectures from the 7th International Geographical Conference CONGEO '07, Brno, Czech Republic. Brno, Institute of Geonics ASCR., p.44-45.

Nový čas, Svištia krajinka vo Vysokých Tatrách: Detský raj vo výške $1751 \mathrm{~m}$, viewed on 2.7.2010. http://www.cas.sk/clanok/171921/svistia-krajinka-vovysokych-tatrach-detsky-raj-vo-vyske-1751-m.html.

Olwig, KR 2005, 'Theme issue: landscape justice, morality and the law of the land', Landscape Research, vol.3o. no.3, p-293-430.

Otahel, J 2003, 'Visual quality of the landscape: approaches to analysis', Ekológia (Bratislava), vol.22. no.2, p.150-16o.

Pocock, D \& Hudson, R 1978, Images of the Urban Environment, McMillan, London.

Powell, JM 1978, Mirrors of the New World: images and image-makers in the settlement process, Australian National University Press, Canberra.

Saarinen, J 2004, 'Destinations in change: the transformation process of tourist destinations', Tourist Studies vol.4. no.2, p.161-179.

Smith, N 2008, Uneven development: Nature, Capital, and the Production of Space, The University of Georgia Press, Athens.

TMR, 2010, Valné zhromaždenie TMR, apríl 2010. Press release viewed on 22.4.2010 http://www.tmr.sk/fileadmin/userupload/tlacovespravy/v z220410.pdf.

UNEP, 2003, Tourism and Local Agenda 21 The Role of Local Authorities in Sustainable Tourism, Paris UNEP - Freiburg ICLEI.

Urry, J 1990a, 'The 'consumption' of tourism', Sociology, vol.24. no.1, p.23-35.

Urry, J 199ob, The Tourist Gaze: Leisure and Travel in Contemporary Societies, Sage, London.

Vos, W \& Klijn, J 2000, 'Trends in European landscape development: prospects for a sustainable future', in J Klijn \& W Vos (eds) From Landscape Ecology to Landscape Science, Wageningen, Kluwer Academic Publishers WLO, p.13-30.

Walmsley, DJ \& Lewis, GJ 1993, People and Environment: Behavioural Approaches in Human Geography, Burnt Mill, Longman Scientific \& Technical, Harlow.

Ward, SV 1998, Selling Places: The Marketing and Promotion of Towns and Cities, 1850-2000, E. and F. N. Spon, London. 